\title{
Homozygous 31 trinucleotide repeats in the SCA2 allele are pathogenic for cerebellar ataxia
}

Maya Tojima, MD, Gaku Murakami, MD, PhD, Rie Hikawa, Hodaka Yamakado, MD, PhD, Hirofumi Yamashita, MD, PhD, Ryosuke Takahashi, MD, PhD, and Masaru Matsui, MD, PhD

Neurol Genet 2018;4:e283. doi:10.1212/NXG.0000000000000283

\author{
Correspondence \\ Dr. Yamashita \\ hirofumi@kuhp.kyoto-u.ac.jp \\ or Dr. Matsui \\ masarum@otsu.jrc.or.jp
}

Spinocerebellar ataxia type 2 (SCA2), an autosomal dominant cerebellar disorder belonging to the polyglutamine (polyQ) diseases, is characterized by progressive ataxia, slow saccadic eye movement, hyporeflexia, peripheral neuropathy, and pyramidal and extrapyramidal signs. ${ }^{1}$ The cause of SCA2 is a CAG repeat expansion, sometimes interrupted by CAA within, in ATXN2 on chromosome $12 \mathrm{q} 24 .{ }^{2,3}$ Previous reports have shown that the presence of 33 or more heterozygous trinucleotide repeats is pathogenic, whereas 14 to 31 repeats is normal. ${ }^{3,4}$ We report a case of late-onset SCA2 with homozygous alleles of 31 trinucleotide repeats in ATXN2.

\section{Case report}

An 80-year-old woman visited our hospital with a 1-year history of slowly progressive gait disturbance. There was no family history of cerebellar ataxia, although her sister was diagnosed with amyotrophic lateral sclerosis (ALS) at 68 years of age and died of respiratory failure at 72 years (figure, A). Our patient had no history of excessive alcohol drinking. Neurologic examination findings showed normal eye movement, mild dysarthria, hyporeflexia of the bilateral patellar and Achilles tendons, ataxia of the lower extremities, unstable standing without aid, and a wide-based ataxic gait. A cognitive examination was normal, with a Mini-Mental State Examination score of 30/30. Blood test results, including thyroid function, albumin, lipids, vitamin E, tumor markers, and CSF analysis were normal. Cranial MRI revealed bilateral cerebellar atrophy, while $N$-isopropyl-p-(iodine-123)-iodoamphetamine SPECT showed hypoperfusion of the brainstem and bilateral cerebellar hemispheres (figure, B). Nerve conduction study and electromyogram findings were normal.

After obtaining informed consent, genomic DNA was extracted from leukocytes. First, we amplified the region containing the trinucleotide repeats in ATXN2 using the primer pair SCA2-A (5'-GGGCCCCTCACCATGTCG-3') and SCA2-B (5'-CGGGCTTGCGGACATTGG-3') and found a single amplicon slightly larger than a normal 22 trinucleotide repeat length (figure, C). Other genes for SCAs, including SCA1, 3, and 6, and DRPLA were normal (data not shown). Next, Sanger sequencing for the ATXN2 repeat region was performed, which demonstrated homozygous $(\mathrm{CAG})_{13} \mathrm{CAA}(\mathrm{CAG})_{8} \mathrm{CAA}(\mathrm{CAG})_{8}$, a total of 31 trinucleotide repeats, and a chromatogram without overlap by another repeat length (figure, D). Finally, we applied whole exome sequencing to exclude other genetic causes of ataxia (table e-1, links.lww.com/ NXG/A111) and found no causative mutation among the candidate genes except the homozygous expansion of trinucleotide repeats in ATXN2 (e-methods, links.lww.com/NXG/A114 and table e-2, links.lww.com/NXG/A112).

\footnotetext{
From the Department of Neurology (M.T., M.M.), Otsu Red Cross Hospital; Department of Neurology (M.T., R.H., H. Yamakado, H. Yamashita, R.T.), Kyoto University Hospital, Otsu, Japan; Murakami Clinic (G.M.), Kyoto, Japan; Department of Neurology (H. Yamashita), Japanese Red Cross Wakayama Medical Center, Wakayama, Japan.

Funding information and disclosures are provided at the end of the article. Full disclosure form information provided by the authors is available with the full text of this article at Neurology.org/NG.

The Article Processing Charge was funded by the authors.

This is an open access article distributed under the terms of the Creative Commons Attribution-NonCommercial-NoDerivatives License 4.0 (CC BY-NC-ND), which permits downloading and sharing the work provided it is properly cited. The work cannot be changed in any way or used commercially without permission from the journal.
} 

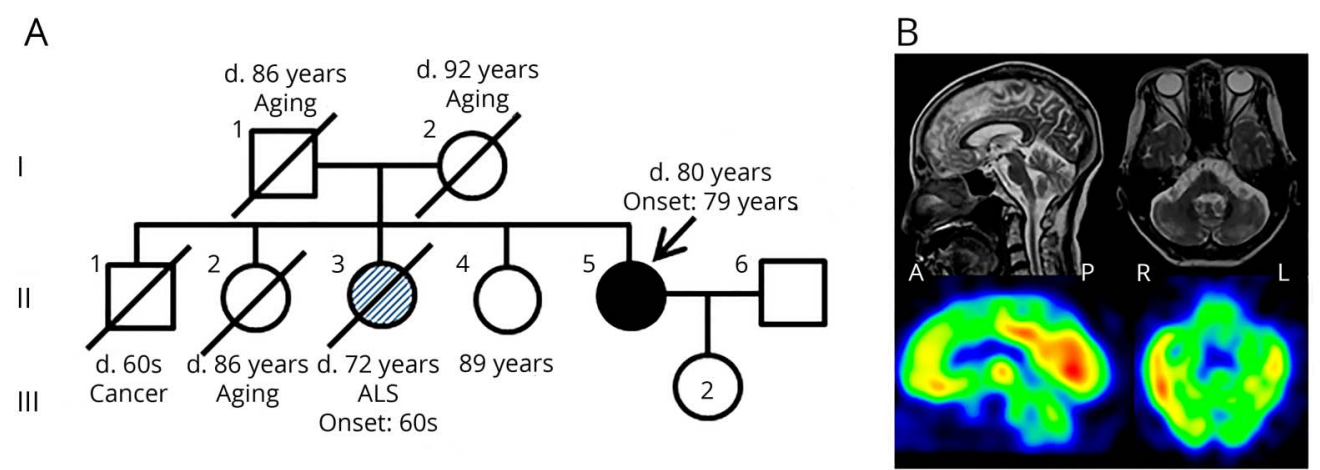

C

$\mathrm{D}$
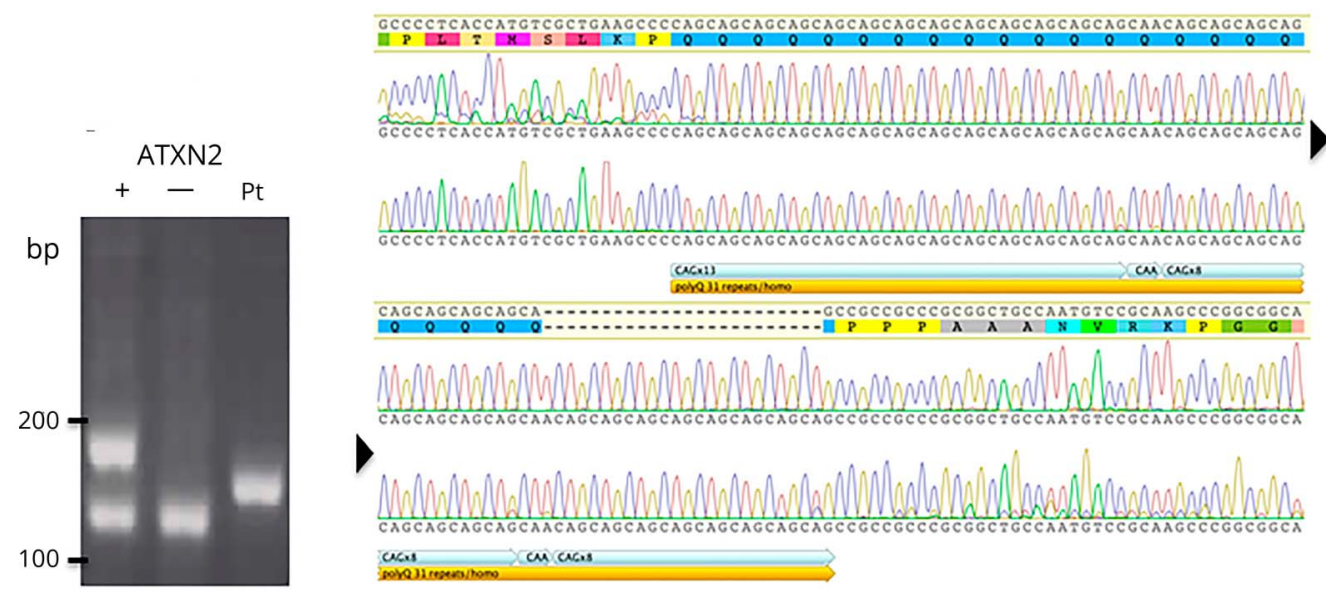

(A) Family pedigree. (B) Upper. MRI showing atrophy of the cerebellar hemispheres. Lower. $N$-isopropyl-p-(iodine-123)-iodoamphetamine SPECT showing hypoperfusion in the brainstem and cerebellar hemispheres. (C) Analysis of PCR-amplified products containing CAG repeats in ATXN2. Plus (+) and minus (-) indicate positive and negative controls, respectively. Pt indicates sample from the present index case. (D) DNA sequence analysis of CAG repeats in ATXN2 of the present index case. Arrowheads indicate continuation. Chromatograms in both directions are shown. That in the upper portion is sequence analysis in the

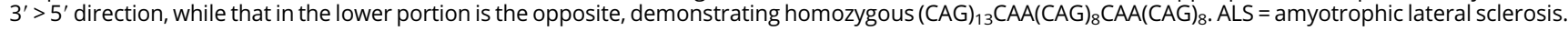

\section{Discussion}

Polyglutamine (polyQ) diseases are neurodegenerative disorders caused by the expansion of a trinucleotide (CAG) repeat, which is translated into an abnormally elongated glutamine $(\mathrm{Q})$ tract in the respective mutant proteins. There are 9 known polyQ diseases, including 6 different spinocerebellar ataxias (SCA1, 2, 3, 6, 7, 17), dentatorubralpallidoluysian atrophy, Huntington's disease, and spinal and bulbar muscular atrophy. All except for SBMA are inherited in an autosomal dominant manner, and each has its own normal, intermediate, and expanded trinucleotide repeat sizes. While there are several reports of cases homozygous for expanded trinucleotide repeat size, cases homozygous for intermediate trinucleotide repeat size are rare. ${ }^{5}$ Furthermore, there is no report of a homozygous normal trinucleotide repeat as causative of disease.

The present clinical findings were consistent with early stage SCA2, and laboratory and gene analysis results ruled out other diseases presenting cerebellar ataxia. Although parental consanguinity of this index case is not clear, the parents may share a common ancestor for 2 reasons: one is that both originated from an isolated area of Okayama Prefecture in Japan, and the other is that the genomic region containing ATXN2 was a homozygous segment suggesting autozygosity (table e-3, links.lww.com/NXG/A113). The sister of the patient with ALS may reflect the association of an intermediate expansion of the trinucleotide repeat in ATXN2 and ALS. ${ }^{6}$

As for the trinucleotide repeat length in ATXN2, 33 repeats are pathogenic (i.e., fully penetrant) and 32 in a homozygous state have been associated with very late-onset cerebellar ataxia, although clinical information has not been published. ${ }^{6}$ Cerebellar ataxia is never caused by 31 repeats in a heterozygous state. Therefore, the present case is important because it shows that a 31 trinucleotide repeat length in ATXN2 in a homozygous state is pathogenic. A pathogenic effect of a homozygous intermediate trinucleotide repeat in SCA6, another polyQ disease, has been demonstrated. ${ }^{5}$ Taken together, in polyQ disease, an intermediate trinucleotide repeat length in a homozygous state has the potential to cause disease because of a gene dosage effect, although the repeat is not necessarily pathogenic in a heterozygous state. 
One available mechanism-based treatment for patients with polyQ disease is reducing the levels of toxic disease-gene products by antisense oligonucleotides, short hairpin RNAs, or miRNAs. ${ }^{7}$ The present case suggests that in polyQ diseases with an intermediate to hopefully mildly expanded trinucleotide repeat length, the reduction of polyQ proteins by $\sim 50 \%$ should substantially mitigate the effects of the disease.

\section{Author contributions}

M. Tojima: study concept and design, acquisition, analysis and interpretation of data, and drafting the manuscript. G. Murakami: study concept and design. R. Hikawa: acquisition and analysis of data. H. Yamakado: study concept and design, analysis and interpretation of data. H. Yamashita: study concept and design, analysis and interpretation of data, study supervision, and critical revision of manuscript for intellectual content. R. Takahashi: study supervision and critical revision of manuscript for intellectual content. M. Matsui: study concept and design, study supervision, and critical revision of manuscript for intellectual content.

\section{Study funding}

No targeted funding reported.

\section{Disclosure}

The authors report no disclosures relevant to the manuscript. Full disclosure form information provided by the authors is available with the full text of this article at Neurology.org/NG.

Received January 17, 2018. Accepted in final form September 26, 2018.

\section{References}

1. Giunti P, Sabbadini G, Sweeney MG, et al. The role of the SCA2 trinucleotide repeat expansion in 89 autosomal dominant cerebellar ataxia families. Frequency, clinical and genetic correlates. Brain 1998;121:459-467.

2. Gispert S, Twells R, Orozco G, et al. Chromosomal assignment of the second locus for autosomal dominant cerebellar ataxia (SCA2) to chromosome 12q23-24.1. Nat Genet 1993;4:295-299.

3. Cancel G, Dürr A, Didierjean O, et al. Molecular and clinical correlations in spinocerebellar ataxia 2: a study of 32 families. Hum Mol Genet 1997;6: 709-715.

4. Sequeiros J, Seneca S, Martindale J. Consensus and controversies in best practices for molecular genetic testing of spinocerebellar ataxias. Eur J Hum Genet 2010;18: 1188-1195.

5. Mariotti C, Gellera C, Grisoli M, Mineri R, Castucci A, Di Donato S. Pathogenic effect of an intermediate-size SCA-6 allele (CAG)(19) in a homozygous patient. Neurology 2001;57:1502-1504.

6. Neuenschwander AG, Thai KK, Figueroa KP, Pulst SM. Amyotrophic lateral sclerosis risk for spinocerebellar ataxia type 2 ATXN2 CAG repeat alleles: a meta-analysis. JAMA Neurol 2014;71:1529-1534.

7. Keiser MS, Kordasiewicz HB, McBride JL. Gene suppression strategies for dominantly inherited neurodegenerative diseases: lessons from Huntington's disease and spinocerebellar ataxia. Hum Mol Genet 2016;25:R53-R64. 


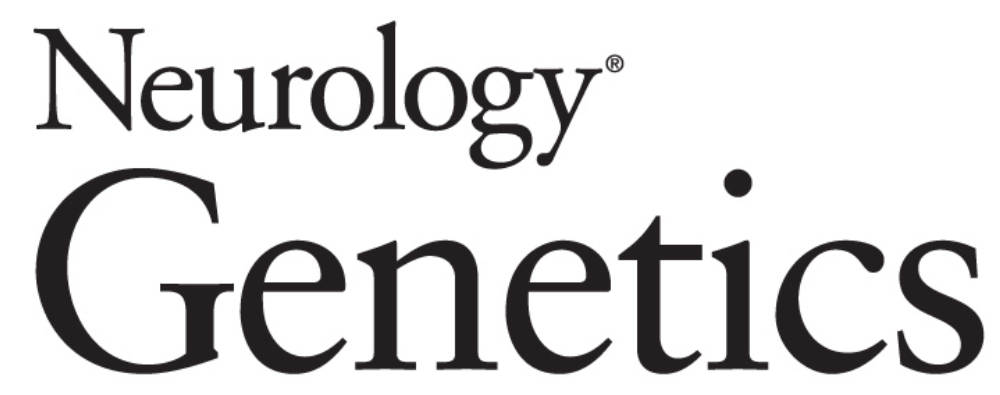

\section{Homozygous 31 trinucleotide repeats in the SCA2 allele are pathogenic for cerebellar ataxia}

Maya Tojima, Gaku Murakami, Rie Hikawa, et al.

Neurol Genet 2018;4;

DOI 10.1212/NXG.0000000000000283

This information is current as of October 16, 2018

\section{Updated Information \& Services}

References

Citations

Subspecialty Collections

Permissions \& Licensing

Reprints including high resolution figures, can be found at: http://ng.neurology.org/content/4/6/e283.full.html

This article cites 7 articles, 0 of which you can access for free at: http://ng.neurology.org/content/4/6/e283.full.html\#\#ref-list-1

This article has been cited by 1 HighWire-hosted articles: http://ng.neurology.org/content/4/6/e283.full.html\#\#otherarticles

This article, along with others on similar topics, appears in the following collection(s):

Spinocerebellar ataxia

http://ng.neurology.org//cgi/collection/spinocerebellar_ataxia

Trinucleotide repeat diseases

http://ng.neurology.org//cgi/collection/trinucleotide_repeat_diseases

Information about reproducing this article in parts (figures,tables) or in its entirety can be found online at:

http://ng.neurology.org/misc/about.xhtml\#permissions

Information about ordering reprints can be found online: http://ng.neurology.org/misc/addir.xhtml\#reprintsus

Neurol Genet is an official journal of the American Academy of Neurology. Published since April 2015, it is an open-access, online-only, continuous publication journal. Copyright Copyright @ 2018 The Author(s). Published by Wolters Kluwer Health, Inc. on behalf of the American Academy of Neurology.. All rights reserved. Online ISSN: 2376-7839.

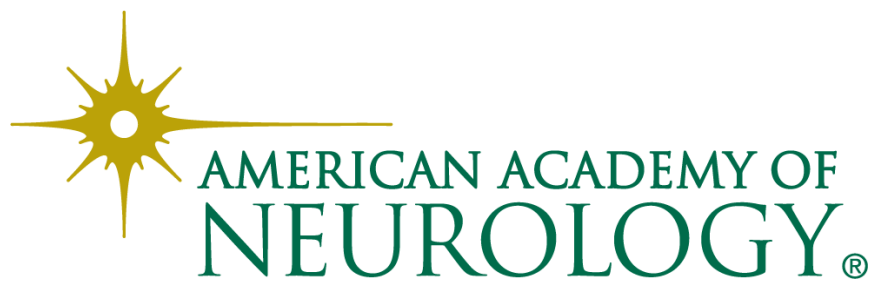

